補緅誌，J Jpn Prosthodont Soc, 38：611〜620, 1994.

\title{
原著論文
}

\section{主成分分析による局部床義歯支台歯喪失の 危険因子について}

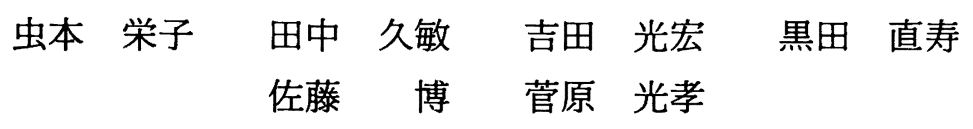

\author{
A Statistical Analysis of Risk Factors Influencing \\ Removable Partial Denture Prognosis
}

\begin{abstract}
Eiko Mushimoto, Hisatoshi Tanaka, Mitsuhiro Yoshida, Naotoshi Kuroda, Hiroshi Sato and Mitsutaka Sugawara
\end{abstract}

\begin{abstract}
Criteria for selection of removable partial denture abutment teeth is broad, depends upon many factors, and its estimation of prognosis there by is difficult. In order to establish diagnostic parameters, the degree of tooth quality must be determined.

The aim of this study was to test via statistical analysis those factors which can affect tooth quality, and provide risk factors influencing removable partial denture abutments.

Subjects including patients requiring extractions of abutment teeth were divided into two groups of vital and nonvital teeth. Data was collected based on clinical examinations, and assigned to various categories of factors.

In the vital group, factor contribution to poor prognosis included periodontal condition, bone resolution, pocket depth and CPITN, which proved to be significant risk factors. In the nonvital group, biomechanical factors, such as occlusal and prosthesis factors, were shown to be significant risk factors.
\end{abstract}

Key words : RPD, statistical analysis, risk factors, RPD prognosis

\section{I. 緒 言}

局部床義歯支台歯の予後に関して, 動摇やう蝕が増

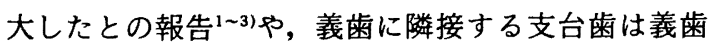

岩手医科大学歯学部歯科補緅学第一講座

Iwate Medical Univ., School of Dentistry Dept. of Removable Prosthodontics

平成 5 年 12 月 10 日受付
に組込まれていない残存歯に比べて歯周状態が悪化し ているとの報告 ${ }^{4 \sim 6)}$ もる。 そのような局部床義歯の 予後に影響を与える 2 大因子には, プラークに起因す る細菌と義歯の静力学に由来する側方応力が考えられ ているが7), 予後不良の原因を考察する際, そのいず れかを 1 次因子としてピックアップするのは困難であ る8).

局部床義歯はその特殊な構成ゆえ, 残存諸組織に対 する有害性が従来より指摘され9), 補緅学では, 支台 
歯の負担軽減を目的として義歯の静力学的考察 ${ }^{10 \sim 12)}$ がなされてきた。一方，スカンジナビアでは，歯周病 学領域を中心に，支台歯歯周組織に対する増悪因子を プラークに求める考え方 ${ }^{6}$ が台頭し，可能であれば局 部床義歯は回避する方が望ましいとの極論9さえあっ た。すなわち歯の喪失原因に医原性疾患の概念を適用 するものである。そのような背景から，Lundquvist $^{13)}$ は, 局部床義歯の予後に関する疫学調査におい て，歯の喪失に関連する要因としてう蝕，歯周炎とは 別に補経物を挙げ，その寄与が予想以上に大きかった と報告した。しかし, 補綴物のいかなる因子が歯の袈 失原因になったのか，また，う蝕や歯周炎との交互作 用の影響はどうなのかなど不明な点が多く残されてい る.

一方，支台歯の選択基準の幅は広く ${ }^{14)}$ ，歯冠修復に よるエナメル質の有無や抜髄処置による生活歯か失活 歯かなど, 支台歯そのものの質的条件は, 従来, ほと んど無視されてきた。

以上の観点から，局部床義歯支台歯の抜去を必要と した症例について, 当該歯を含め, 1 口腔単位の歯 周, 咬合, 義歯の設計などの詳細な臨床診査を行い, 歯そのものの質的条件として今回は生活歯と失活歯に 大別し, 主成分分析による多変量解析を行って, 局部 床義歯の支台歯喪失の危険因子を検討した。

\section{II. 研究方法}

\section{1. 調査対象とデータ収集}

咀啷障害を主訴として岩手医科大学歯学部付属病院 第 1 補経科外来に来院した局部床義歯患者のうち，支 台歯の抜去を必要とした症例に対し, 問診のほか, 抜

表 1 診査項目

\begin{tabular}{|c|c|}
\hline 年齢 & 総残存崡数 \\
\hline 義歯使用年数 & 同顎残存歯数 \\
\hline Plaque Control Record (PCR) & Eichner の分類 \\
\hline 口腔清掃回数 & Kennedy の分類 \\
\hline う蝕状況 & 対額の補綴物 \\
\hline 骨吸収度 & 咬合様式 \\
\hline Pocket Depth (PD) & 歯冠歯根比 \\
\hline Mobility (Mo) & 支台歯数 \\
\hline Gingival Index (GI) & 鉤間線数 \\
\hline 1 口腔平均 Pocket Depth (PD) & クラスプ形態 \\
\hline 1口腔平均 Mobility（Mo） & スプリント状況 \\
\hline 1 口腔平均 Gingival Index (GI) & 歯冠修復状況 \\
\hline CPITN & 失活処置歯の有無 \\
\hline
\end{tabular}

去支台歯を含めた 1 口腔単位の口腔内診査, X 線診 査，および義歯の診査など，独自のプロトコールを用 いて広範囲に調査を行った。分析対象は，それらの記 載が明確で，本研究で定めた分析資料に欠測值のない 52 症例（抜去歯 66 本中, 生活歯 31 本, 失活歯 35 本）である。なお，データの収集に際して，検者間で の評価のばらつきをなくすため, 同一検者が調査を 行った。

\section{2. 分析方法}

本研究の目的は，局部床義歯支台歯が抜去に至った 原因に関し，生活歯と失活歯それぞれにどのような要 因がより密接であるのかを臨床所見から収集した可及 的に多くの情報から推測することにあった。 そこで， 歯の喪失原因や局部床義歯の予後に関する従来の報告 を参考にして，収集した多数の診査項目の中から本研 究では 25 項目を変数として選んだ（表 1)。これらの 説明変数は，残存歯数など数量データはそのまま入力 し，一方，クラスプ形態や Kennedy の分類といった カテゴリーデータでは義歯の静力学と歯周衛生面など 局部床義歯支台歯にとっての装置の適性度，不利益性 または病態の重篤度など勾配のあるデー夕の質を十分 考慮し，数量化して用いた（表 2)。なお $\mathrm{CPITN}^{15)}$ は，WHOにより定められた CPITN の評価に準じて 行った.

得られたデー夕は，生活歯と失活歯それぞれの群で 項目ごとに集計し，平均值と分散を求めた。また必要 に応じて分散分析し，本研究の母集団の特徵を把握し て, 生活歯群と失活歯群との違いの有無を検討した。 また，生活歯と失活歯それぞれの群で，変数間の相互

表 2 カテゴリー項目の点数

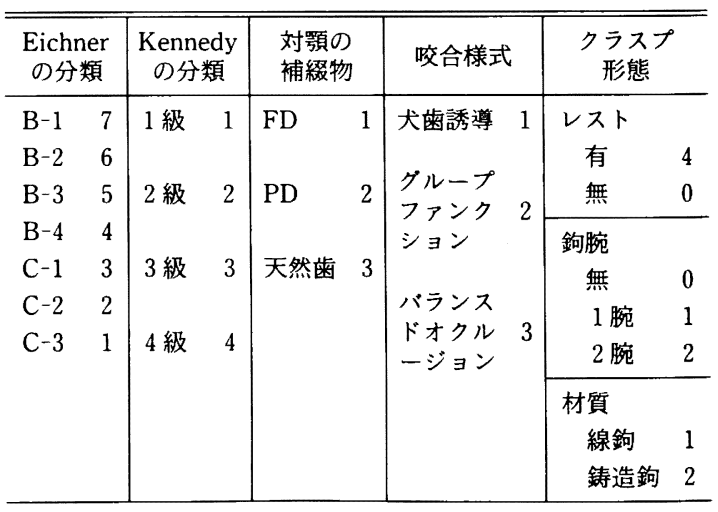

注：クラスプ形態はレスト・鉤腕・材質の総計とした 
表 3 分析患者の特徵

\begin{tabular}{|c|c|c|c|c|c|}
\hline \multirow[b]{2}{*}{ 年齢 } & \multicolumn{2}{|c|}{$\begin{array}{c}\text { 生 活 歯 } \\
\text { 平均 標準偏差 }\end{array}$} & \multicolumn{2}{|c|}{$\begin{array}{c}\text { 失 活 曾 } \\
\text { 平均 標準偏差 }\end{array}$} & \multirow[t]{2}{*}{$\begin{array}{c}\text { 分散分析 } \\
\text { P 值 }\end{array}$} \\
\hline & 58.5 & 9.2 & 61.6 & 9.3 & \\
\hline 義歯使用年数 & 3.4 & 4.7 & 4.5 & 4.4 & \\
\hline PCR & 61.3 & 17.5 & 63.8 & 20.0 & \\
\hline 口腔清掃回数 & 1.5 & & 1.9 & & \\
\hline う蝕状況 & 0.6 & 1.0 & 1.0 & 1.4 & \\
\hline 骨吸収度 & 60.9 & 14.9 & 48.3 & 21.3 & $\mathrm{P}<0.01$ \\
\hline $\mathrm{PD}$ & 7.0 & 1.6 & 5.8 & 1.9 & $\mathrm{P}<0.01$ \\
\hline Mo & 2.4 & 0.6 & 2.0 & 1.0 & \\
\hline GI & 1.8 & 0.8 & 1.6 & 0.7 & \\
\hline PI & 2.4 & 0.5 & 2.3 & 0.7 & \\
\hline 1 口腔平均 PD & 4.8 & 1.6 & 3.6 & 1.3 & $\mathrm{P}<0.01$ \\
\hline 1 口腔平均 Mo & 1.0 & 0.7 & 0.8 & 0.6 & \\
\hline 1 口腔平均 GI & 1.2 & 0.7 & 1.1 & 0.5 & \\
\hline 1 口腔平均 PI & 1.8 & 0.5 & 1.9 & 0.5 & \\
\hline CPITN & 3.2 & 0.9 & 2.6 & 1.1 & $\mathrm{P}<0.025$ \\
\hline 総残存歯数 & 11.4 & 4.7 & 12.2 & 4.9 & \\
\hline 同額残存歯数 & 5.3 & 2.5 & 6.1 & 2.6 & \\
\hline 歯冠歯根比 & 0.5 & 0.4 & 0.6 & 0.6 & \\
\hline 支台歯数 & 3.2 & 1.2 & 2.9 & 1.1 & \\
\hline レスト数 & 2.4 & 1.4 & 2.3 & 1.4 & \\
\hline 銁間線数 & 1.7 & 0.9 & 1.4 & 0.8 & \\
\hline スプリント状況 & 0.2 & 0.5 & 0.3 & 0.7 & \\
\hline 歯冠修復状況 & 0.7 & 0.8 & 1.8 & 0.4 & \\
\hline
\end{tabular}

関係を分析し，変数に共通して含まれる要素の抽出を 試み，支台歯が抜歯に至ったと思われる因子を推定す るために, 主成分分析による多変量解析 ${ }^{16)}$ を適用し た。なお，演算処理は東北大学大型計算機センター ACOS-2 用, STAT PAC-2/4/6 を用いた。

\section{III. 結 果}

\section{1. 分析患者群の診査結果と特徵}

分析対象とした局部床義歯患者の診査結果を生活歯 群と失活歯群とで比較し，その特徵をまとめた（表 $3)$.

1）被検者について

被検者の平均年齢は, 生活歯群の 59 歳に対し, 失 活歯群では 62 歳とやや高いものの有意差はなく, 性 別は生活歯群では男性 21 名に対して女性 10 名と少な く，失活歯群では逆でそれぞれ 15 名と 20 名であった (図 1).

2）残存歯数と欠損分布の分類

抜去歯と同一顎の残存歯数は, 生活歯群が 5.3 本, 失活歯群が 6.1 本と差がなく, 上下顎あわせた総残存

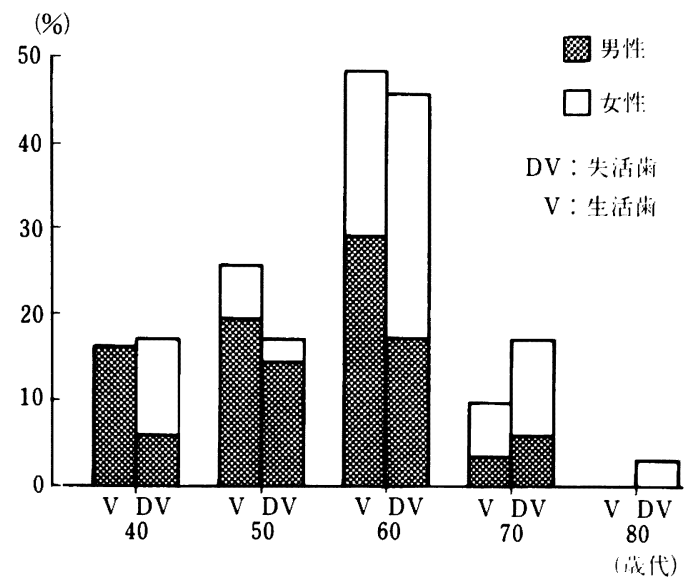

図 1 年齢分布

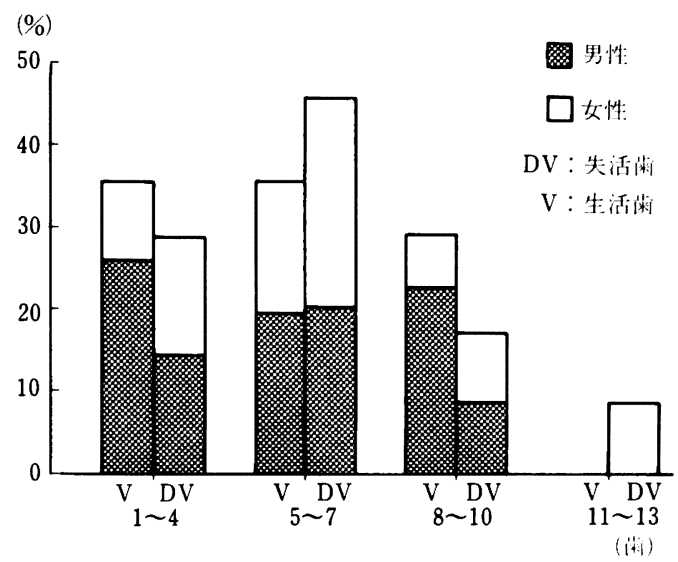

図 2 残存歯数

歯数でもそれぞれ 11.4 本, 12.2 本と両群間に有意差 はなかった（図 2 )。

欠損分布を Kennedy の分類からみると, 生活歯群 ではI 級が $61 \%$ ＩI 級が $32 \% ，$ 失活歯群ではそれぞ れ $57 \%$ ，28\% といずれも遊離端症例が $80 \%$ を越えて いた（図 3 )。一方，咬合の支持域を Eichner の分類 でみると，生活歯群では B-3 が $52 \% ， B-2$ が $16 \%$, 失活歯群ではそれぞれ $31 \% ， 29 \%$ で，咬合支持のな い分類 C は生活歯群の $16 \%$ に対して，失活歯群では $31 \%$ と約 2 倍であった（図 4 ）.

\section{3）抜去被検歯}

抜去された被検歯は，両群とも犬歯，小臼歯が大半 を占めていたが，支台歯としての使用年数は，生活歯 群, 失活歯群とも 1 年末満から 10 年以上に広範にば らつき，平均ではそれぞれ 3.4 年， 4.5 年で失活歯群 でやや長かったが有意差は認めなかった。 
失活蔽

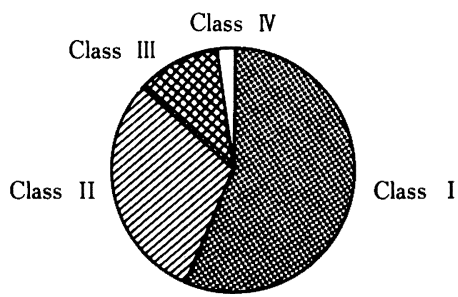

生活蔽

Class IV

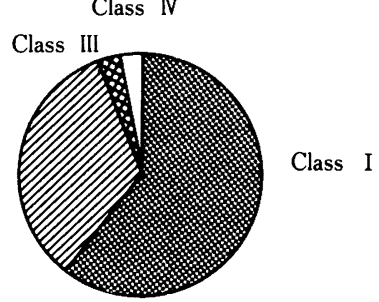

図 3 Kennedy の分類

失活料

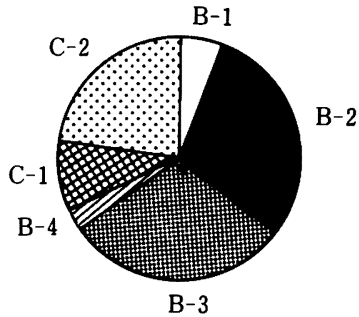

生活鳖

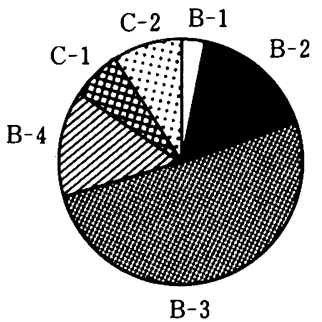

図 4 Eichner の分類

う蝕䍜患率は, 生活歯群の $32 \%$ に対し, 失活歯群 では $51 \%$ と著しく高く，内容は根面う蝕が多かった。 また歯冠修復状況は，生活歯群では $26 \%$ に全部鋳造 冠処置が施されていたのに対し，失活歯群では $86 \%$

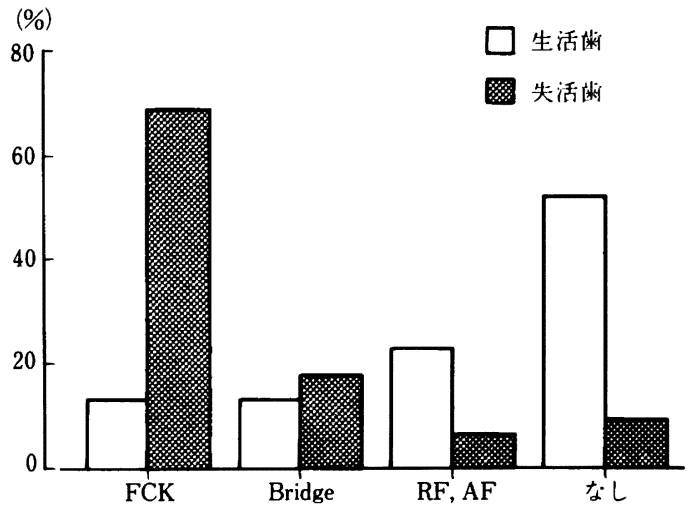

図 5 歯冠修復状況

と 3 倍で，う蝕との関連がうかがわれた（図 5 ).

一方，歯根を分子にとって求めた歯冠歯根比は，生 活歯群の 0.5 に対し, 失活歯群では 0.6 とやや大き かったが有意差はなかった。

4）歯周組織の状態

抜去歯の歯周組織の診査結果では, Pocket Depth (以下 PD とする) のみに有意差を認め, 生活歯群で は $7.0 \mathrm{~mm}$ であったのに対し, 失活歯群では $5.8 \mathrm{~mm}$ と浅かった. Mobility（以下Moとする）と Gingival Index (以下 GI とする) では生活歯群と失活歯 群でそれぞれ $2.4,2.0$ および $1.8,1.6$ と有意差は認 めなかった。抜去歯以外の 1 口腔の平均值でも生活歯 群の PDの $4.8 \mathrm{~mm}$ に対し, 失活歯群では $3.6 \mathrm{~mm}$ と 有意に浅く, Mo では生活歯 1.0 , 失活歯 0.8, GI て は生活歯 1.2 , 失活歯 1.1 といずれも失活歯群でやや 歯周状態は良好だったが有意差は認めなかった。

そこで 1 口腔単位で歯周疾患䍜患状況が把握できる ことから CPITN をみると, 生活歯群の 3.2 に対して 失活歯群では 2.6 と有意に小さく,やはり生活歯群の 歯周状態は全体的に不良であることが明らかだった (図 6).

5）義歯および維持装置

支台歯数は, 生活歯群で 3.2 本, 失活歯群で 2.9 本 と有意差を認めず，鉤間線数でも同じく 1.7 本と 1.4 本と差がなかった．またクラスプ形態においても，線 鉤の比率は生活歯群 $83 \%$, 失活歯群 $90 \%$ とほほ同じ で，平均レスト数でも生活歯群と失活歯群でそれぞれ 2.4 個と 2.3 個と差がなかった。しかし，破損などで レストのなくなっていたクラスプは, 生活歯群では $52 \%$ と半数を占め, 失活歯群でも $39 \%$ に達し, また 鉤腕がなくなっていたものもそれぞれ14\%，19\%を 

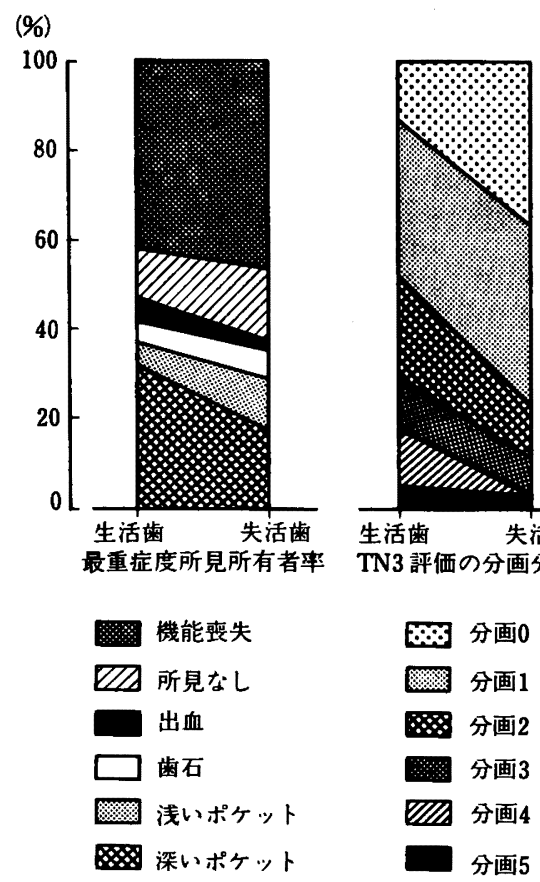

図 6 CPITN

占めていた。

\section{2. 主成分分析結果}

表 4〜6に生活歯と失活歯それぞれの主成分分析結 果の Correlation Matrix, 固有べクル，および因 子負荷量を示した．分析結果からいずれの群でも第 3 主成分までで累積寄与率は $50 \%$ となっていたことか らここでは第 4 主成分以下は省略した. Correlation Matrix は, 口腔清掃に関する部分を示し, 特に生活 歯群と失活歯群との違いは認められなかった。さらに 生活歯の固有べクトルの表から, 第 1 主成分では 1 口 腔平均でみた PD, Mo，GI といったペリオ関連の係 数が負の方向に值が大きく，第 2 主成分では総および 同領残存歯数, Kennedy の分類, 鈎間線数など残存 歯数関連の係数が正の方向に值が大きく，第 3 主成分 では Plaque Control Record（以下 PCR とする) が 正で，対額の補綴物が負の方向で值が大きかった。一 方, 失活菌では, 第 1 主成分では, 総残存歯数, Eichner の分類, 対䫛の補緅物が負の方向で值が大き く, 第 2 主成分では抜去歯の PD が正の, 歯冠歯根比 が負の方向に值が大きく，第 3 主成分ではう蝕が正の 方向で大きかった。

因子負荷量については各変数の位置が必ず半径 1 の
表 4 Correlation Matrix

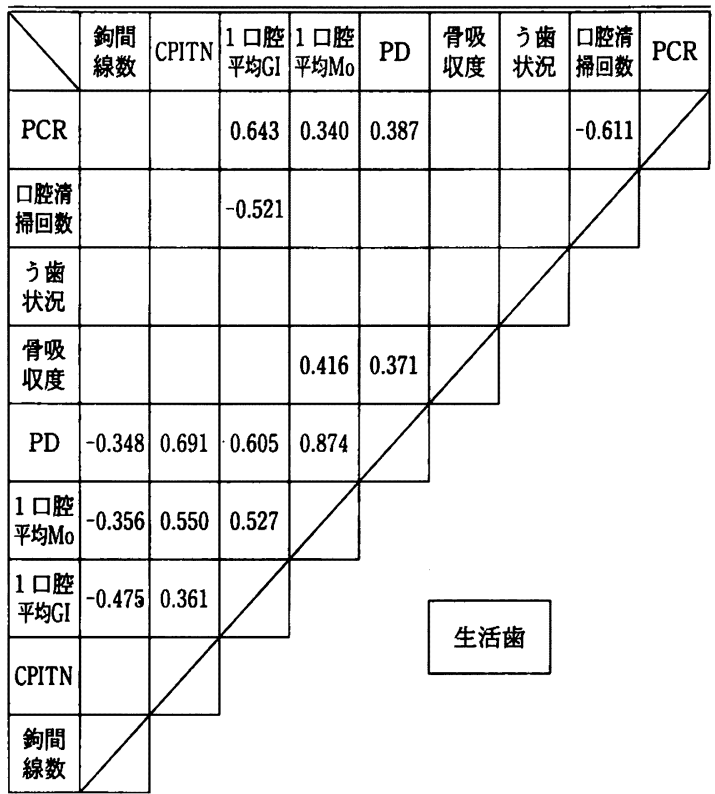

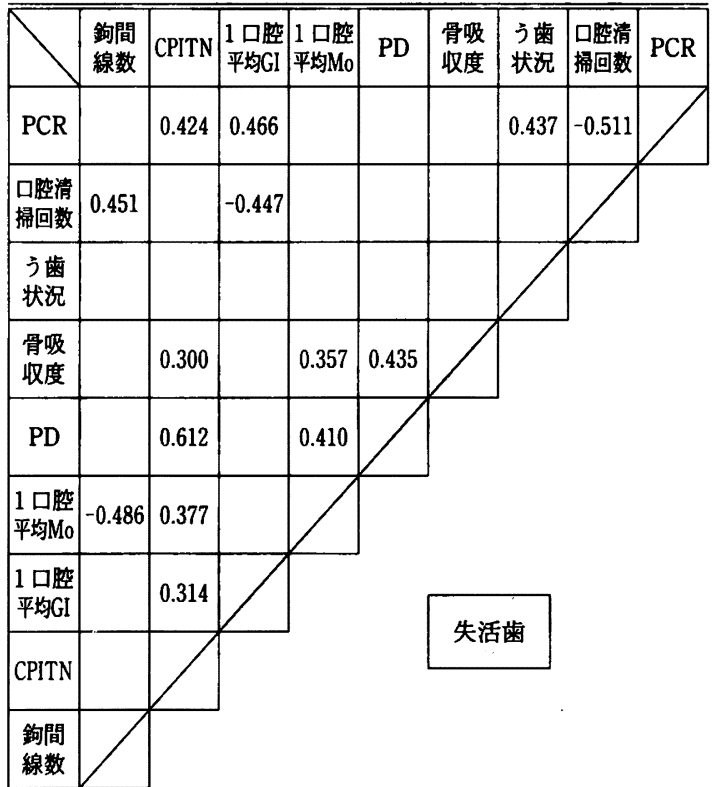

円内に表されるという Factor Loding Plot ${ }^{17)}$ として 図解した（図 7,8）。

図 7 は生活歯群の第 1 主成分を横軸に, 第 2 主成分 を縦軸にとってそれぞれの変数の因子負荷量をプロッ トしたものである. 横軸の左偏に群をなす負の変数 は, 抜去歯の GI と PD, 1 口腔平均の GI, PD, およ びMo, CPITN, 骨吸収度, PCR といずれも歯周疾 
表 5 主成分分析（固有ベクトル）

\begin{tabular}{|c|c|c|c|c|c|c|}
\hline 変 数 & \multicolumn{3}{|c|}{$\begin{array}{c}\text { 生 活 曾 } \\
\text { 主成分 } 1 \text { 主成分 } 2 \text { 主成分 } 3\end{array}$} & \multicolumn{3}{|c|}{$\begin{array}{l}\text { 失 活 歯 } \\
1 \text { 主成分 } 2 \text { 主成分 } 3\end{array}$} \\
\hline 1 年齢 & 24 & 7 & -0.047 & 0.170 & 0.1 & 0.27 \\
\hline 2 義歯使用年数 & 0.257 & 0.007 & 0.224 & 0.203 & -0.125 & 0.120 \\
\hline 3 PCR & -0.159 & -0.087 & 0.376 & 0.220 & 0.208 & 0.283 \\
\hline 4 口腔清掃回数 & 0.112 & -0.024 & -0.232 & 0.052 & -0.287 & -0.211 \\
\hline 5 う蝕状況 & -0.021 & -0.242 & -0.145 & 0.108 & -0.003 & 0.411 \\
\hline 6 骨吸収度 & -0.257 & -0.149 & -0.299 & 0.092 & 0.293 & -0.186 \\
\hline $7 \mathrm{PD}$ & -0.235 & -0.019 & -0.113 & -0.070 & 0.325 & -0.143 \\
\hline $8 \mathrm{Mo}$ & -0.083 & 0.026 & -0.004 & 0.177 & 0.179 & -0.306 \\
\hline $9 \mathrm{GI}$ & -0.276 & 0.051 & -0.057 & -0.020 & 0.148 & 0.089 \\
\hline 101口腔平 & -0.364 & -0.014 & 0.102 & 0.065 & 0.296 & -0.220 \\
\hline 111 口腔平均 $\mathrm{Mo}$ & -0.350 & 0.002 & 0.119 & 0.251 & 0.101 & -0.256 \\
\hline 121 口腔平均 GI & -0.314 & 0.029 & 0.248 & 0.059 & 0.180 & 0.266 \\
\hline 13 CPITN & -0.265 & -0.068 & 0.062 & 0.226 & 0.276 & -0.039 \\
\hline 14 総残存歯数 & 0.067 & 0.385 & -0.248 & -0.405 & 0.033 & -0.097 \\
\hline 15 同領残存雪数 & 0.049 & 0.380 & 0.092 & -0.170 & -0.007 & -0.264 \\
\hline 16 Eichner の分類 & -0.057 & 0.283 & -0.185 & -0.373 & 0.121 & -0.108 \\
\hline 17 Kennedy の分類 & 0.024 & 0.365 & -0.151 & -0.211 & 0.210 & 0.173 \\
\hline 18 対額の補綴物 & 0.021 & 0.153 & -0.402 & -0.342 & 0.045 & -0.005 \\
\hline 19 咬合様式 & 0.034 & -0.231 & -0.048 & -0.057 & -0.136 & 0.079 \\
\hline 20 歯冠歯根比 & 0.252 & 0.126 & 0.310 & -0.155 & -0.338 & 0.148 \\
\hline 21 支台菌数 & -0.176 & 0.301 & 0.224 & -0.209 & 0.230 & -0.015 \\
\hline 22 銁間線数 & -0.117 & 0.327 & 0.065 & -0.251 & 0.229 & 0.156 \\
\hline 23 クラスプ形態 & 0.227 & -0.045 & -0.050 & -0.102 & -0.209 & -0.098 \\
\hline 24 スプリント状況 & 0.120 & 0.057 & 0.151 & -0.167 & -0.003 & 0.183 \\
\hline 25 歯冠修復状況 & 0.249 & 0.040 & 0.254 & 0.173 & -0.209 & -0.226 \\
\hline
\end{tabular}

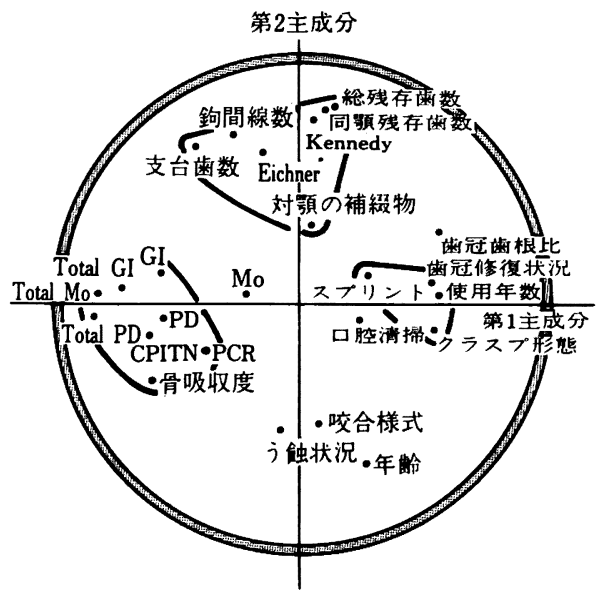

图 7 生活歯における Factor Loding Plot

患に関連する変数が密接（円で囲まれる）で，一方， 右偏には正のスプリント, クラスプ形態, 歯冠修復状 態が群化でき，第 1 主成分の特性は「ペリオ要因対補 綴要因」を示した。一方, 縌軸では, 総残存歯数, 同 顎残存歯数, 支台歯数, Kennedy の分類, Eichner
表 6 主成分分析（因子負荷量）

\begin{tabular}{|c|c|c|c|c|c|c|}
\hline 変 数 & \multicolumn{3}{|c|}{$\begin{array}{c}\text { 生 活 歯 } \\
\text { 主成分 } 1 \text { 主成分 } 2 \text { 主成分 } 3\end{array}$} & \multicolumn{3}{|c|}{$\begin{array}{c}\text { 失 活 歯 } \\
\text { 主成分 } 1 \text { 主成分 } 2 \text { 主成分 } 3\end{array}$} \\
\hline 1 年齢 & & -0.645 & -0.087 & 0.376 & 0.259 & 0.483 \\
\hline 2 義䨑使用 & 0.5 & 0.014 & 0.408 & 0.448 & -0.260 & 0.209 \\
\hline $3 \mathrm{PCR}$ & -0.369 & -0.184 & 0.687 & 0.485 & 0.433 & 0.492 \\
\hline 4 口腔注 & 0.260 & -0.051 & -0.424 & 0.115 & -0.597 & -0.366 \\
\hline $5 う$ & -0.049 & -0.507 & -0.264 & 0.204 & 0.611 & -0.324 \\
\hline 6 骨吸収度 & -0.596 & -0.313 & -0.545 & -0.156 & 0.677 & -0.249 \\
\hline $7 \mathrm{PD}$ & -0.544 & -0.040 & -0.207 & 0.392 & 0.373 & -0.531 \\
\hline $8 \mathrm{Mo}$ & -0.193 & 0.055 & -0.008 & -0.045 & 0.308 & 0.155 \\
\hline $9 \mathrm{GI}$ & -0.640 & 0.107 & -0.103 & 0.498 & 0.576 & -0.068 \\
\hline 101 & -0.843 & -0. & 0.187 & -0.895 & 0.069 & -0.169 \\
\hline 111 口腔平均 Mo & -0.812 & 0.004 & 0.218 & -0.377 & -0.015 & -0.460 \\
\hline t平均 $\mathrm{GI}$ & -0.728 & 0.060 & 0.453 & -0.824 & 0.252 & -0.189 \\
\hline & -0.615 & -0.142 & 0.114 & -0.465 & 0.437 & 0.300 \\
\hline 孜歯数 & 0.157 & 0.808 & -0.453 & -0.756 & 0.094 & -0.010 \\
\hline 15 & 0. & 0.798 & 0.167 & -0.126 & -0.283 & 0.137 \\
\hline $16 \mathrm{E}$ & -0.132 & 0.594 & -0.338 & -0.343 & -0.703 & 0.258 \\
\hline $17 \mathrm{~K}$ & 0.056 & 0.764 & -0.276 & -0.461 & 0.479 & -0.027 \\
\hline 18 & 0.050 & 0.321 & -0.732 & -0.554 & 0.478 & 0.271 \\
\hline 19 咬合様式 & 0.080 & -0.485 & -0.087 & -0.225 & -0.436 & -0.170 \\
\hline 20 每冠歯根上 & 0.584 & 0.264 & 0.565 & 0.239 & -0.007 & 0.714 \\
\hline 21 支台 & -0.408 & 0.632 & 0.409 & -0.370 & -0.007 & 0.318 \\
\hline 22 鉤間線数 & -0.272 & 0.685 & 0.118 & 0.383 & -0.435 & -0.392 \\
\hline 23 クラスプ形 & 0.527 & -0.094 & -0.092 & 0.143 & 0.617 & -0.383 \\
\hline 24 スプリントサ & 0.278 & 0.119 & 0.276 & 0.555 & 0.211 & -0.444 \\
\hline 25 歯冠修復状況 & 0.578 & 0.085 & 0.464 & 0.131 & 0.374 & 0.462 \\
\hline
\end{tabular}

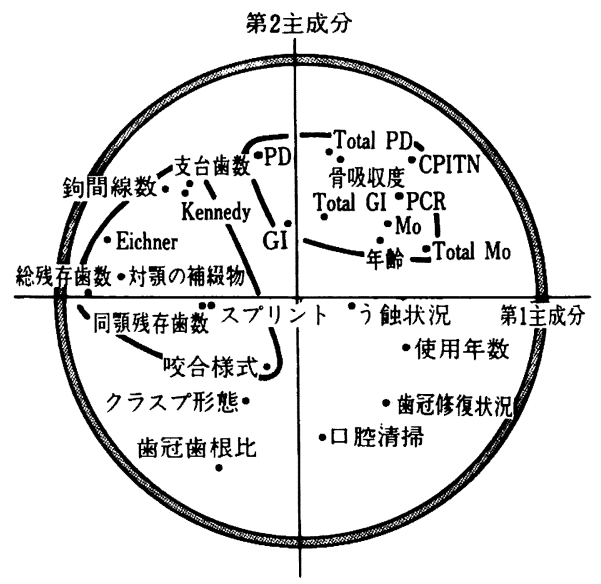

図 8 失活蒾における Factor Loding Plot

の分類，対效の補綴物などが正の方向に值が大きく， 第 2 主成分の特性は歯の残存歯の数に関連する変数か ら「咬合要因」と推測できる.

図 8 は同じく失活歯群の第 1 主成分と第 2 主成分と をプロットしたものである. 横軸左偏には負の因子負 
荷量を示した総残存歯数, 対靧の補経物, Kennedy の分類, Eichner の分類, 支台歯数, 銁間線数など残 存歯数に関連する変数が群をなし, 第 1 主成分の特性 は「咬合関連要因」であると思われる。一方, 綎軸に は, 抜去歯 PD, GI, Mo, 1 口腔平均 PD, GI, Mo, 骨吸収度, CPITN, PCR, 年齢などが正の值で群を なし，第 2 主成分は「ペリオ要因」であると推測でき た.

\section{IV. 考察}

高齢化社会を迎え, 80 歳で 20 本の歯を残そうとい う 8020 運動が広がっている.どうすれば歯をできる だけ長く保存できるかを考える場合, 逆に何が歯の喪 失原因になるのかを明らかにする必要が生じる。そこ でまず，歯を支えている歯周組織に障害を及ほす要因 を, 一方では歯そのものの寿命を変化させる要因を究 明することが必要となる。

歯そのものの寿命とは, 歯の耐久性を意味し, これ に影響を及ほすすものとして,メカニカル因子では歯に 加わる応力 ${ }^{18}$ が生物学的には細菌侵醉 ${ }^{19}$ が考えられ る.つまり, 過剩診療や不良な修復物に起因する医原 性疾患も避けて通れない問題であり,これらの明確な 把握が必要である。

以上のことから本研究では歯質の脆弱化に無関係で ない抜㖪処置に着目し，歯の喪失への危険因子の説明 変数に義歯などの修復要因も加え, 支台歯の抜髄処置 の有無すなわち生活歯と失活歯とに対するこれらの変 数の関わりを検討した.

\section{1. 研究方法について}

局部床義歯やその支台歯の予後に関する報告は多い が, 大半が個々人の症例報告であり, 大母集団におけ る系統だった研究1-5,20 28)でも実態調査的なものがほ とんどであった。

そこで, 本研究ではむしろ局部床義歯の予後への増 悪因子を追究することを目的とした. 情報収集に際

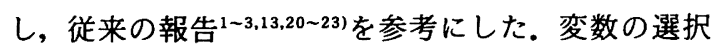
に際して, 2 大要因として従来どおり衛生的因子と力 学的因子9は考慮したが，これらは歯周組織や義歯側 の要素であり, 歯そのものの質的問題は無視されてい る. 支台歯選択の基準 ${ }^{14)}$ は常識的にとり扱われ, 実際 にはそのレベルにひらきがある。これらの諸因子は, 支台歯の修復処置によるエナメル質の有無や抜髄処置
による生活歯か失活歯などのさまざまな質的条件が違 えばその影響の結果は当然異なるものと推測される. そこで本研究では, 局部床義歯装着後に支台歯の抜去 を余儀なくされた患者群を母集団とし, 義歯使用年数 を支台歯の寿命に近似して取り扱い，歯の質的条件設 定をした。

選択した変数は，25 項目と多く，また変数間での 交互作用効果も考慮する必要があったことから, 主成 分分析による多変量解析を応用した。これによって複 数の変量間での密接度から生活歯群と失活歯群それぞ れに成分特性の抽出を試みた。

\section{2. 変量の選択と数量化}

支台歯喪失に影響を及ほしたと思われる因子を選択 するために，支台歯の抜去を必要とした症例の詳細な 臨床的診査を行い, 従来から局部床義歯の予後あるい は経過観察の報告にみられる支台雪への增悪因子も参 考にして 25 項目を説明変数として選択した.

これらの変数のうち数值で得られたものはそのまま データとしたが, う蝕, 欠損形態, 咬合条件, 義歯条 件などカテゴリーデータも含まれており，スケーリン グ ${ }^{29)}$ が必要であった。この数量化に際して，尺度評定 の妥当性が問題となることが報告されているが30), 本 研究で採用した変数は，患者の心理状態などの主観的 データではなく, 病態の重篤度や装置の適性度といっ た勾配をもった段階順に評定しやすいデータであった ことから，スケーリングに際して特別に重みずけや尺 度距離の加減の必要性は認めなかった ${ }^{311}$.

\section{3. 研究結果について}

1) 歯周診查について

診査結果で生活歯と失活歯との群間に有意性を認め たのは, PD, 骨吸収度,およびCPITNだけで，い ずれも生活歯群で值が大きく，そのほかの歯周診查か ら得られた変数においてもすへて歯周状態は生活歯群 で不良な傾向を示した。これらの理由としては生活歯 群の構成において $68 \%$ が男性であり, 口腔清掃の平 均回数が少なかったこと融との関連が推測できた。こ のことは Correlation Matrix（表 4) で口腔清掃と 1 口腔平均 $\mathrm{GI}$ に負の相関（R=-0.521）があったこ とからも理解できる. 一方, 失活歯群では口腔の衛生 管理関連の変数と歯周診查関連の変数とには相関はな かった. 
2) 残存歯の数について

生活歯群では $93 \%$ が, 失活歯群では $85 \%$ が遊離端 欠損で，抜去歯との同頡および上下頡総残存歯数とも 生活歯群で僅かに少なく, 歯冠歯根比も生活歯群で不 良傾向を示した. しかし残存歯数と歯周診査の関係を 相関でみると, 失活歯群で負の相関関係を多く認め, 残存歯が少ないことと歯周状態の悪化傾向の関連が推 測された。

3）義歯診査および支台歯の修復と口腔状態につい $\tau$

支台歯数，銁間線数，クラスプ形態とレスト数，お よびスプリント状況において生活歯群でやや多いもの のほとんど差はなかった。しかし，歯冠修復状況にお いて失活歯群は生活歯群の 3 倍と修復率が著しく高 く,これに呼応してう蝕罹患率は 1.5 倍を呈し, しか も 3 面におよぶ歯根面う蝕が多くみられた。したがつ て, 失活歯群では抜髄処置から歯冠修復, そして 2 次 う蝕罹患という歯科治療における望ましくない定型パ ターンが推測された。

また, 生活歯群ではスプリント状況や歯冠修復と骨 吸収度とに負の相関を認め, 補緅前処置との関連が推 測され，適切な補緅前処置が施されていれば支台歯の 骨吸収は少ないと考えることもできる。これに対し， 失活歯群ではクラスプ形態と口腔清掃回数に正の相関 を認め, 維持装置が良好な患者では口腔衛生管理も良 かったが，スプリント状況と支台歯使用年数とに負の 相関を認めたことから補経・修復処置の多いことは逆 に支台歯の Life span を短縮する傾向もみられた。

4）因子負荷量プロット図について

得られた各主成分の特性は生活歯群と失活歯群とで は異なっていた（図 7，8）。第 1 主成分では生活歯群 が「ペリオ要因対補経要因」であり, 第 2 主成分は 「咬合要因」と考えられたが, 失活歯群では第 1 主成 分と第 2 主成分が逆となってそれぞれ「咬合要因」と 「ペリオ要因」であったことから，歯の岥失に及ほすす 危険因子は生活歯と失活歯とではやや異なるものと推 測できた. 特に, 生活歯群では, ペリオ要因と補綴要 因が反比例の関係にあって, 補経・修復処置が多いと 歯周病の重篤度を表す各歯周インデックスの值は小さ く, または補綴・修復処置が少ないと歯周状態は増悪 していると考えることができる.したがって，歯周炎 の原因ないしは増悪因子として, 歯科処置の多寡とい うよりむしろ処置内容の良・不良あるいは適・不適が 問題となると考えられ, 義歯による歯周病の増悪現象
という局部床義歯有害論 ${ }^{9,13)}$ は直接支持できないこと になる。

しかも, 義歯使用年数はペリオ要因と正負が等距離 の関係にあって，しかも歯周インデックスが小さいと 使用年数は長く, 大きいと短いという結果が得られ, また歯冠歯根比は骨吸収度はじめぺリオ要因とは第 1 と第 3 象限において等距離を示すことなどから, 生活 歯群における局部床義歯支台歯賷失の要因のほとんど は歯周疾患の重篤度に関連すると推測された。

一方，失活歯群では，第 4 象限の義歯使用年数と歯 冠修復とが第 2 象限の支台歯数, 鉤間線数, および Kennedyの分類など残存歯数に依存する変数と等距 離の相対する関係にあって, 残存歯数が多ければ支台 歯の Life span とは反比例すること，歯冠修復が少な いかその逆の関係が, また, 第 3 象限の歯冠歯根比々 クラスプ形態が第 1 象限のペリオ要因と等距離の関係 にあって, しかも反比例することから，生活歯群は失 活歯群に比べてぺリオ, 咬合, 補緅要因がいっそう複 雑に関連しあっていると考えられ, 特に咬合や補綴要 因に含まれる歯に加わる力などむしろメカニカルな要 素が支台歯賈失の危険因子として抽出された.

\section{V. 結 論}

局部床義歯支台歯培失の危険因子を推定することを 目的として，支台歯の抜去を余儀なくされた症例につ き抜去歯から生活歯群と失活歯群とにわけ, 1 口腔単 位での臨床診查を変数としてそれぞれ主成分分析を行 い, 次の結果を得た.

1. 分析対象患者において, 年齢, 義歯使用年数, 義歯構成，残存歯数などに生活歯群と失活歯群とに大 きな違いはなかった。

2. 1 口腔単位でみた歯周状態では, 骨吸収度, $\mathrm{PD}$ およびCPITNにおいて有意差を認め, いずれ も生活歯群で不良であった。

3. 主成分分析の固有ベクトルおよび因子負荷量の 結果から, 生活歯群と失活歯群とでは各変数の関わり 程度に異なった特徵がみられ, ペリオ要因, 咬合要 因，補緅要因に大別できた。

4. 因子負荷量プロット図から, 各主成分の成分特 性が生活歯群と失活歯群とでは異なり, 生活歯群の第 1 主成分は「ペリオ要因対補綴要因」, 第 2 主成分は 「咬合要因」であった。一方, 失活歯群では第 1 主成 分は「咬合要因」, 第 2 主成分は「ペリオ要因」で 
あった。

5. 測定した変数間の相互関連状況から, 生活歯群 ではぺリオ要因と使用年数, またぺリオ要因と補綴要 因が相反する因子として関連し, 補緅治療の多夏が必 ずしも医原性疾患に直接つながらないこと，歯周病の 重篤度が支台歯使用年数に影響することがうかがわれ た.これに対し, 失活歯群ではペリオ要因, 咬合要 因,および補経要因がより複雑に関連しあい,むしろ 咬合や補綴要因に起因する歯に加わる力の要素との密 接な関わりが推測された。

以上のことから，局部床義歯支台歯喪失の危険因子 として, 生活歯ではペリオ要因が, 失活歯では咬合や 補綴要因に含まれるメカニカルな因子が示唆された.

\section{文献}

1) Carlsson, G.E., Hedegard, B. and Koivumaa, K.K. : Studies in partial dental prosthesis, III. A longitudinal study of mandibular partial dentures with double extension saddles, Acta Odontol Scand, $20: 95 \sim 119,1962$.

2) Carlsson, G.E., Hedegard, B. and Koivumaa, K.K. : Studies in partial dental prosthesis, IV. Final results of a 4-year longitudinal investigation of dentogingivally supported partial dentures, Acta Odontol Scand, 23 : 443 472, 1965.

3) Carlsson, G.E., Hedegard, B. and Koivumaa, K.K. : Late results of treatment with partial dentures, J Oral Rehabil, $3: 267 \sim 272,1976$.

4) Brill, N., Tryde, G., Stolz, E.A. et al: Ecological changes in the oral cavity caused by removable partial dentures, J Prosthet Dent, $38:$ 138 148, 1977.

5) Addy, M. and Bates, J.F. : Plaque accumulation following the wearing of different types of removable partial dentures, J Oral Rehabil, $2: 111 \sim 117,1979$.

6) Wilding, R.J.C. and Reddy, J. : Periodontal disease in partial denture wearers-a biological index, J Oral Rehabil, 14 : 114〜124, 1987.

7）虫本栄子：スカンジナビアにおけるパーシャルデンチャー の現状, 日歯評論, $437: 103 \sim 111,1979$.

8) 虫本栄子：パーシャルテンチャーと歯周病(1)〜(5)一パーシ ヤルデンチャーは雬周保存に役立つメディアとなりうる か?, 日歯評論, $546: 57 \sim 68,547: 57 \sim 69,548: 67 \sim 82$, $549: 61 \sim 73,551: 79 \sim 88,1988$.

9) Waerhaug, J. : Periodontology and partial prosthesis, Int Dent J, $18: 101 \sim 107,1968$.

10) Kantorowicz, A. : Zur Statik der partiellen Prothese, D. Z.Z., $4:$ 141 162, 1949.
11) Steffel, V.L. : Fundamental principles involved in partial denture design, J Am Dent Assoc, 42:534 544, 1951.

12) Spiekermann, H. and Grüundler, H. (三谷春保, 虫本栄 子) : Die Modellguss-Prothese, (ワンピースキャストパ ーシャル, クインテッセンス出版, 東京, 1978) 1977.

13) Lundquvist, C. : Tooth mortality in Sweden, A statistical survey of tooth loss in the swedish population, Acta Odontol Scand, 25:289 322, 1967.

14) Voss, R. : Grenzen der prosthetischn Therapie, D.Z.Z., $21: 80 \sim 87,1966$.

15) 鈴木恵三: CPITN (Community Periodontal Index of Treatment Needs) の実施にあたって整理すべき事項, 日䨑評論, $513: 161 \sim 180,1985$.

16）古谷野亘：多変量解析ガイド, 126 147, 川島書店, 東京, 1988.

17）田中 豊, 垂水共之, 脇本和昌：パソコン統計解析ハンド ブック II, 160〜166, 共立出版, 東京, 1984.

18) William, C.L. and Eakle, W.S. : Possible role of tensile stress in the etiology of cervical erosive lesions of teeth, J Prosthet Dent, 52:374 380, 1984.

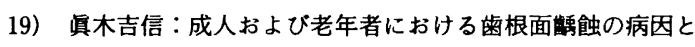
疫学, 日雬医師会誌, $45: 13 \sim 25,1992$.

20）雨森 洋, 奥野正孝, 郡司和彦ほか：部分床義柬の予後に 関する臨床的研究 (II)，第 2 報 部分床義歯の使用状態 について，補緅誌，12：155〜171，1968.

21）雨森 洋, 星野敬二郎, 細井紀雄ほか：部分床義歯の予後 に関する臨床的研究 (II)，第 4 報 粘膜への影響, 補経 誌, $13: 61 \sim 71,1969$.

22）雨森 洋, 梶井 徽, 星野敬二郎ほか：部分床義歯の予後 に関する臨床的研究 (II)，第 5 報 鉤菌のう蝕につい て, 補緅誌, $13: 72 \sim 82,1969$.

23）雨森 洋, 細井紀雄, 石渡秸弘ほか：部分床義歯の予後に 関する臨床的研究 (II)，第 6 報 鈎歯の動摇度変化につ いて, 補緅誌, $15: 134 \sim 143,1971$.

24) Bergman, N., Hugoson, A. and Olsson, C.O. : Periodontal and prosthetic conditions in patients treated with removable partial dentures and artificial crowns, A longitudinal two-year study, Acta Odontol Scand, $29: 621 \sim 638,1971$.

25) Bergman, N., Hugoson, A. and Olsson, C.O. : Caries and periodontal status in patients fitted with removable partial dentures, J Clin Periodontol, 4 : 134 146, 1977.

26) Bergman, N., Hugoson, A. and Olsson, C.O. : Caries, periodontal and prosthetic findings in patients with removable partial dentures: A ten-year longitudinal study, J Prosthet Dent, 48: 506 514, 1982.

27) Schwalm, C.A., Smith, D.E. and Erickson, J.D. : A clinical study of patients 1 to 2 years after placement of 
removable partial dentures, J Prosthet Dent, $38: 380$ 391, 1977.

28) Chandler, J.A. and Brudvik, J.S. : Clinical evaluation of patients eight to nine years after placement of remov. able partial dentures, J Prosthet Dent, $51: 736 \sim 743$, 1984.

29）林知巳夫, 駒澤 勉：数量化理論とデータ処理, 11〜44, 朝
倉書店，東京, 1984.

30）堀田浩史，山辺芳久，白石和宏ほか：義歯治療に対する患 者満足度評定尺度法の妥当性，補緅誌，36:524～532， 1992.

31）一戸孝七，高橋 敬：Personal communication：1993.

32）棉原悠紀田郎, 金子芳洋, 能美光房：1987 雪科衛生の動 向, 日本口腔衛生学会編, 33〜 57, 医歯薬出版, 東京, 1987. 